\title{
Lignin monomer composition affects Arabidopsis cell-wall degradability after liquid hot water pretreatment
}

\author{
$\mathrm{Xu} \mathrm{\textrm {Li } ^ { 1 \dagger }}$, Eduardo Ximenes${ }^{2+}$, Youngmi Kim², Mary Slininger ${ }^{2}$, Richard Meilan ${ }^{3}$, Michael Ladisch ${ }^{2,4^{*}}$, Clint Chapple ${ }^{1^{*}}$
}

\begin{abstract}
Background: Lignin is embedded in the plant cell wall matrix, and impedes the enzymatic saccharification of lignocellulosic feedstocks. To investigate whether enzymatic digestibility of cell wall materials can be improved by altering the relative abundance of the two major lignin monomers, guaiacyl (G) and syringyl (S) subunits, we compared the degradability of cell wall material from wild-type Arabidopsis thaliana with a mutant line and a genetically modified line, the lignins of which are enriched in $G$ and $S$ subunits, respectively.

Results: Arabidopsis tissue containing G- and S-rich lignins had the same saccharification performance as the wild type when subjected to enzyme hydrolysis without pretreatment. After a 24-hour incubation period, less than 30\% of the total glucan was hydrolyzed. By contrast, when liquid hot water (LHW) pretreatment was included before enzyme hydrolysis, the S-lignin-rich tissue gave a much higher glucose yield than either the wild-type or G-ligninrich tissue. Applying a hot-water washing step after the pretreatment did not lead to a further increase in final glucose yield, but the initial hydrolytic rate was doubled.

Conclusions: Our analyses using the model plant $A$. thaliana revealed that lignin composition affects the enzymatic digestibility of LHW pretreated plant material. Pretreatment is more effective in enhancing the saccharification of A. thaliana cell walls that contain S-rich lignin. Increasing lignin S monomer content through genetic engineering may be a promising approach to increase the efficiency and reduce the cost of biomass to biofuel conversion.
\end{abstract}

\section{Background}

Utilization of lignocellulosic biomass for biofuel production requires the hydrolysis of cellulose and other cellwall polysaccharides to their component monosaccharides. This process is affected by many structural and compositional characteristics of the biomass, including the presence of lignin, a phenolic polymer composed of three major types of building blocks: $p$-hydroxyphenyl $(\mathrm{H})$, guaiacyl $(\mathrm{G})$ and syringyl $(\mathrm{S})$ units. The association between lignin and the recalcitrance of biomass materials has long been recognized in forage feeding and tree

\footnotetext{
* Correspondence: ladisch@purdue.edu; chapple@purdue.edu

+ Contributed equally

'Department of Biochemistry, Purdue University, West Lafayette, IN 47907 USA

${ }^{2}$ Department of Agricultural and Biological Engineering and the Laboratory of Renewable Resources Engineering, Purdue University, West Lafayette, IN 47907, USA

Full list of author information is available at the end of the article
}

pulping practices, and led to earlier lignin-engineering efforts aimed at improving feedstock performance in these processes [1]. For example, it has been shown that lignin content (the total amount of lignin in the tissue) greatly influences forage digestibility [2], and that lignin composition (the relative ratio of its component subunits) strongly affects the efficiency of the chemical pulping process. Specifically, transgenic poplar trees with higher S/G ratios show a greatly enhanced pulping efficiency [3]. A recent analysis of transgenic alfalfa revealed that high lignin content is correlated with the recalcitrance of cell-wall materials to enzymatic saccharification during biofuel production [4]. There was little variation in the S:G ratios of these alfalfa lines and as a result, the effects of lignin composition on the efficiency of biomass to biofuel conversion remain to be determined.
C Biomed Central

() 2010 Li et al; licensee BioMed Central Ltd. This is an Open Access article distributed under the terms of the Creative Commons Attribution License (http://creativecommons.org/licenses/by/2.0), which permits unrestricted use, distribution, and reproduction in any medium, provided the original work is properly cited. 
To investigate the effect of S-lignin composition on biomass degradability, we chose to analyze two $A$. thaliana lines in which the activity or expression of ferulate 5 -hydroxylase $(\mathrm{F} 5 \mathrm{H})$, a key enzyme required for the synthesis of S-lignin monomer, is eliminated or enhanced, respectively. Both lines have been generated previously and characterized in detail [5-8]. The fah1-2 mutant is defective in $\mathrm{F} 5 \mathrm{H}$ and does not deposit $\mathrm{S}$ lignin, whereas overexpression of $\mathrm{F} 5 \mathrm{H}$ under the control of the cinnamate 4-hydroxylase $(\mathrm{C} 4 \mathrm{H})$ promoter in the $\mathrm{C} 4 \mathrm{H}: \mathrm{F} 5 \mathrm{H}$ transgenic line results in lignin with an S-unit content in excess of 90\% [6]. These lines represent two extremes in lignin composition and are each distinct from the wild type, which deposits a G/S copolymer with an S-subunit content of approximately $20 \mathrm{~mol} \%$. Despite their lignin difference, these two lines show similar growth to that of wild-type Arabidopsis.

In the biomass to biofuel conversion processes, pretreatment is generally used to increase the accessibility of cell-wall polysaccharides to enzymes. Pressure-cooking in liquid hot water (LHW) has been shown to be a cost-effective pretreatment to enhance the enzymatic digestibility of cellulose in a variety of feedstocks [9-12]. In this study, we assessed the cell-wall degradability of mutant and transgenic A. thaliana lines by enzyme hydrolysis without pretreatment, after LHW pretreatment, or after LHW pretreatment followed by hot water washing. Our results indicate that increasing the proportion of S subunits in Arabidopsis lignin decreases the recalcitrance of cell walls to enzymatic hydrolysis.

\section{Results}

\section{Composition analysis}

Consistent with previously published results [6], the lignins of fah1-2 and C4H:F5H plants are dominated by $\mathrm{G}$ and $S$ subunits, respectively (Table 1 ). In contrast to the drastic differences in lignin composition, other cell-wall components of fah1-2 and C4H:F5H plants are relatively unchanged (Table 1). Whereas fah1-2 is similar to the wild type in glucan, xylan and acetyl content, C4H:F5H has slightly lower values for these components. Arabinan was not detected in any of the samples analyzed.
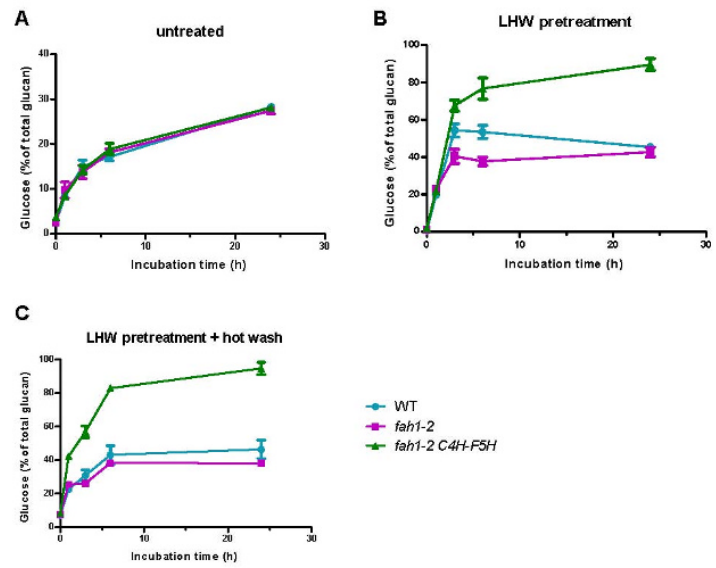

Figure 1 Enzyme hydrolysis of stem material . Enzyme hydrolysis time-course of (A) untreated, (B) liquid hot water (LHW)-pretreated, and (B) LHW-pretreated and hot-washed wild-type and genetically modified Arabidopsis. thaliana samples ( $2 \%(\mathrm{w} / \mathrm{V})$ using a mixture of cellulase (Spezyme CP 50 filter paper units/g glucan or $90 \mathrm{mg}$ protein/g glucan) and $\beta$-glucosidase (Novozyme 188100 cellobiase units/g glucan or $34 \mathrm{mg}$ protein/g glucan) at $50^{\circ} \mathrm{C}$ and $\mathrm{pH} 4.8$.

\section{Enzyme hydrolysis of untreated samples}

As a first step to evaluate the possible effect of $S$ lignin composition changes on cell-wall degradability, mature stems from wild-type, fah1-2 and C4H:F5H plants were subjected to enzyme hydrolysis without any pretreatment. There was limited cellulose hydrolysis in untreated stems (Figure 1A). After 24 hours of incubation, only about $30 \%$ of the maximum theoretical glucose yield was obtained for wild-type samples. The lowand high-S lignin samples have similar hydrolysis kinetics and glucose yield to those of the wild type, indicating that the structural changes to lignin in those plants do not have a significant effect on enzymatic hydrolysis of cellulose in untreated cell-wall materials.

\section{Enzyme hydrolysis with LHW pretreatment}

We further tested the cell-wall degradability of the lines by applying LHW pretreatment before enzyme

Table 1 Derivatization followed by reductive cleavage (DRFC) lignin and compositional analysis of Arabidopsis thaliana samples ${ }^{1}$

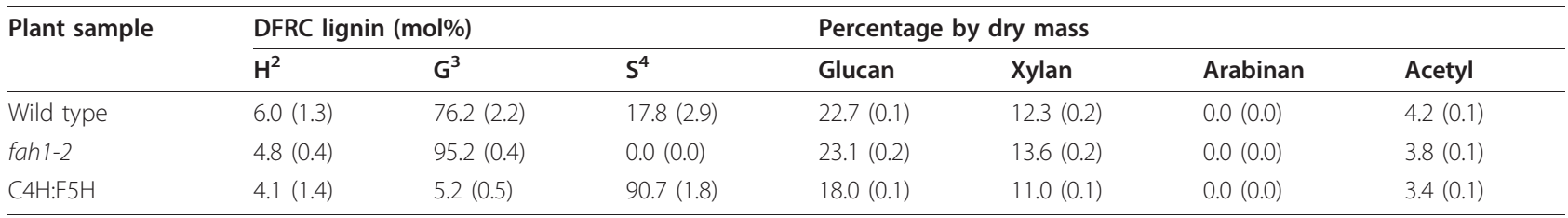

${ }^{1}$ Mean values of three biological replications are represented, with standard errors shown in brackets.

${ }^{2} \mathrm{H}=p$-hydroxyphenyl.

${ }^{3} \mathrm{G}=$ guaiacyl,

${ }^{4} \mathrm{~S}=$ syringyl, 
hydrolysis. Regardless of genotype, the hydrolytic rate and glucose yield of pretreated samples was greater than for the corresponding untreated samples (Figure 1B). Incubation of LHW-pretreated wild-type samples with enzymes for 1 hour released the same amount of glucose (20\% of total glucan) as 6 hours of hydrolysis on untreated samples. More importantly, significant differences in cellulose hydrolysis were observed for LHWpretreated fah1-2 and C4H:F5H samples (Figure 1B).No differences in glucose yield between the three genotypes were observed after 1 hour of incubation, but after 3 hours of incubation, C4H:F5H yielded more glucose and fah1-2 less glucose, compared with wild type. After 24 hours, the glucose yield of the $\mathrm{C} 4 \mathrm{H}: \mathrm{F} 5 \mathrm{H}$ sample was nearly $90 \%$.

\section{Scanning electronic microscopy}

Pretreatment causes structural and/or chemical changes of biomass materials, making cellulose more accessible to hydrolytic enzymes [13]. To determine whether any anatomical changes occurred during LHW pretreatment and enzyme hydrolysis, we performed scanning electron microscopy (SEM) on stem cross-sections that had been subjected to different treatments. The wild-type, fah1-2 and $\mathrm{C} 4 \mathrm{H}: \mathrm{F} 5 \mathrm{H}$ stems had similar vascular patterning (Figure 2). LHW pretreatment broke the pith cells and caused the detachment of the phloem from the xylem. This happened in all three genotypes, but fah1-2 had more intact pith cells compared with the wild type and $\mathrm{C} 4 \mathrm{H}: \mathrm{F} 5 \mathrm{H}$. In samples that underwent enzyme hydrolysis without pretreatment, both phloem and pith cells were completely disrupted, and there were no significant differences between the different genotypes. Interestingly, the stem cross-sections of $\mathrm{C} 4 \mathrm{H}$ :F5H that had undergone LHW pretreatment plus enzyme hydrolysis were found to have collapsed, which was not observed in wild-type and fah1-2 samples after the same treatment.

Our enzyme hydrolysis results suggest that LHW pretreatment is differentially effective against $A$. thaliana samples with altered lignin composition.

\section{Enzyme hydrolysis after LHW pretreatment and hot-water washing}

It has been shown that hot-water washing of LHW pretreated poplar can further improve its enzymatic digestibility [11]. Therefore, we also tested the cell-wall degradability of the A. thaliana samples after this additional step (Figure 1C). Unlike poplar, hot-water washing did not have a significant effect on the total glucose yield as calculated based on the initial glucan content of the Arabidopsis samples tested; however, the initial rate of cellulose hydrolysis of hot-water washed $\mathrm{C} 4 \mathrm{H}: \mathrm{F} 5 \mathrm{H}$ samples was almost double that of unwashed samples. By contrast, hot-water washing has little effect on the initial hydrolytic rate of the wild-type and fah1-2 samples.

\section{Phenolic inhibitors analysis}

The previous results suggest that hot-water washing may remove inhibitors of cellulase and/or $\beta$-glucosidase activity from $\mathrm{C} 4 \mathrm{H}: \mathrm{F} 5 \mathrm{H}$ samples. To investigate this possibility, we analyzed the total content of phenolics in the liquid fraction after LHW pretreatment. All three genotypes had a similar concentration of total phenolics, approximately $0.3 \mathrm{mg} / \mathrm{ml}$ tannic acid equivalent (Table 2 ). This concentration is lower than the level known to significantly inhibit cellulose, although deactivation of these enzymes, particularly $\beta$-glucosidase may occur over a 24 -hour period $[14,15]$.

\section{Discussion}

Lignin is a major contributor to the recalcitrance of biomass, and has been a target for feedstock improvement through genetic engineering. It has been demonstrated in several plant species that a reduction in lignin content using transgenic approaches enhances cell-wall degradability; however, significant improvement in conversion efficiency has often been accompanied by abnormal plant growth and development [1,4]. By contrast, plants seem to be amenable to wide ranges in lignin composition changes, including variation in the content of conventional monomers and the incorporation of atypical precursors [6,16-18]. Our findings of improved cell-wall degradability in Arabidopsis stems with high Slignin content demonstrate the potential of lignin composition modification for the improvement of cellulosic feedstock performance.

LHW treatment had a dramatic effect on enzyme hydrolysis of biomass from the high S-lignin line. As much as $90 \%$ of the maximum theoretical glucose yield was achieved for $\mathrm{C} 4 \mathrm{H}: \mathrm{F} 5 \mathrm{H}$ tissue, whereas less than $60 \%$ was obtained from wild-type material exposed to the same treatment. SEM analysis detected no obvious anatomical differences between the low and high S-lignin samples after LHW pretreatment. By contrast, after LHW pretreatment and enzyme hydrolysis, stem crosssections from the high S-lignin stems had a distinct deformity, presumably due to enhanced hydrolysis of the cell wall.

How alteration of lignin composition relates to the observed increase in the effectiveness of LHW pretreatment is unclear. Recently, it was proposed that during high-temperature pretreatment, lignin is melted and relocalized to outer surface of the cell wall, increasing the accessibility of the cellulose within $[19,20]$. The S:G ratio is known to have profound effects on lignin structure. Whereas G-rich lignin has a branched structure, Srich lignin is more linear and has a lower degree of 


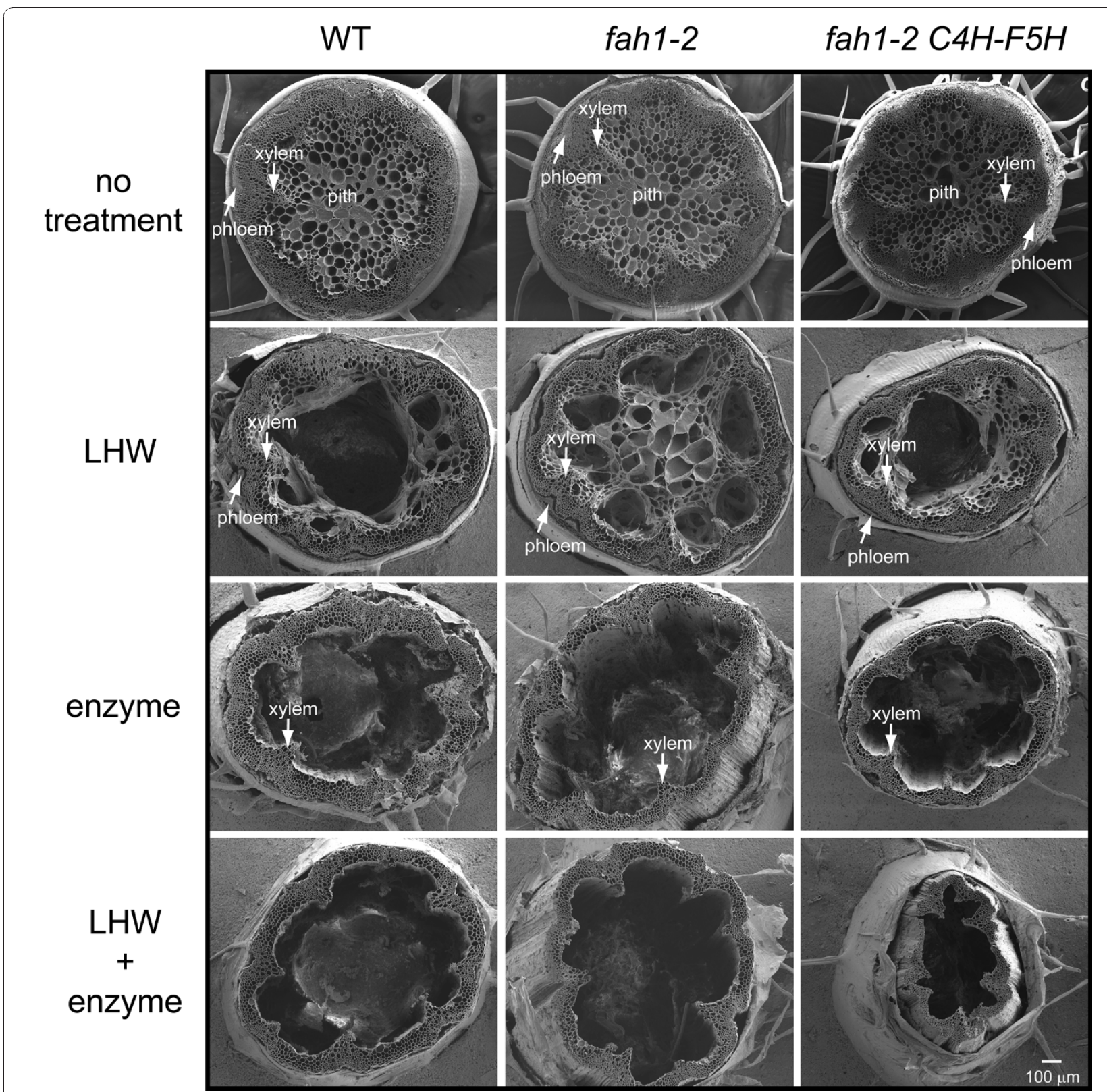

Figure 2 Scanning electron microscopy (SEM) of stem cross-sections subjected to various treatments . Wild-type, fah 1-2 and C4H:F5H stems were cross-sectioned and affixed to a glass slide. Sections received either no treatment or one of the following treatments: liquid hot water (LHW) pretreatment, enzyme digestion, or LHW pretreatment plus enzyme digestion. Afterwards, they were imaged by SEM.

Table 2 Concentration of total phenolics in liquid collected after liquid hot water pre-treatment. ${ }^{1,2}$

\begin{tabular}{ll}
\hline $\begin{array}{l}\text { Arabidopsis } \\
\text { samples }\end{array}$ & Concentration of total phenolics, $\mathbf{m g ~ T A E} / \mathrm{ml}^{3}$ \\
\hline Wild type & $0.30 \pm 0.19$ \\
fahl-2 & $0.35 \pm 0.01$ \\
C4H:F5H & $0.30 \pm 0.08$ \\
\hline
\end{tabular}

${ }^{1}$ Liquid was collected by centrifugation $(3,000 \mathrm{rpm}, 20 \mathrm{~min})$ after liquid hot water pretreatment $\left(200^{\circ} \mathrm{C}, 10 \mathrm{~min}\right.$ and $\left.30 \mathrm{sec}\right)$ of Arabidopsis samples $(2 \%$ $(w / v))$.

${ }^{2}$ Data are mean \pm SE of three biological replications.

${ }^{3} \mathrm{TAE}=$ tannic acid equivalent. polymerization [21]. It is tempting to speculate that Srich lignin may have a lower melting point and is more easily relocated than G-rich lignin and, thereby, leads to improved enzymatic digestibility.

The observation that hot-water washing after LHW pretreatment significantly increases the initial saccharification rate of the high-S sample suggests removal of some inhibitory compounds. It has been shown LHW pretreatment of wet cake (solids left after corn is fermented to ethanol) releases some phenolics and water soluble xylo-oligosaccharides that can inhibit cellulases 
and $\beta$-glucosidases [14]. However, in this study, the concentration of phenolics in the liquid after LHW pretreatment was below the level reported to cause significant inhibition. Moreover, we did not see any difference in the concentration of phenolics between Sdeficient, S-rich and wild-type $A$. thaliana tissue samples. Therefore, it is unlikely that the observed increase in saccharification rate was due to the removal of inhibitors. The relative influence of phenolic molecules on enzyme activity becomes more pronounced as the ratio of phenols to protein increases at higher solid and lower protein loadings than used in this study. Although protein loadings are currently in the range of 2 to $10 \mathrm{mg} / \mathrm{g}$ lignocellulose solids, which represent up to a five-fold decrease in enzyme from only 5 years ago, an even greater reduction is needed for economically viable processes [13,22].

It will be important to extend this study to other biomass feedstocks in the future. One of the factors that needs to be considered is the native lignin composition of different plant species, and possibly also the interaction of lignin with the polysaccharide components of the cell wall. It is likely that the dramatic increase in cell-wall degradability observed in Arabidopsis might be less apparent in plant species with high native S-lignin levels, such as hybrid poplar. However, significant increases in lignin extractability during the pulping process has been observed in S-lignin-enriched transgenic poplar [3], suggesting that the magnitude of S lignin increase may still contribute significantly to higher cellwall degradability in this important biomass feedstock.

\section{Conclusions}

The available genetically modified $A$. thaliana plants with different lignin composition and structure provided an opportunity to evaluate the possible effect of lignin modification on cell-wall recalcitrance. Our study revealed that high levels of S-lignin have a positive effect on the effectiveness of LHW pretreatment and enzymatic hydrolysis, at least in Arabidopsis. This effect might result from the physicochemical changes of lignin brought about by more linear structure of $\mathrm{S}$ subunits. In the future, it will be important to determine how widespread is this phenomenon and to elucidate its underlying mechanism.

\section{Methods \\ Materials}

Generation of the A. thaliana fah1-2 and $\mathrm{C} 4 \mathrm{H}: \mathrm{F} 5 \mathrm{H}$ lines has been described previously [6,7]. The genetically modified and wild-type $A$. thaliana (Columbia) plants were grown side by side at $22^{\circ} \mathrm{C}$ under a 16 -hour photoperiod. Mature stems were harvested by removing siliques and leaves.
Spezyme CP cellulase preparation from Trichoderma reesei containing exo-, endo- and $\beta$-glucosidase activities; batch number 3016295230) was provided by Genencor, Danisco Division (Palo Alto, CA, USA). Novozyme 188 ( $\beta$-glucosidase from Aspergillus niger; catalogue number c6150) was purchased from Sigma Chemical Co. (St. Louis, MO, USA).

\section{Lignin analysis}

Lignin composition was determined using the derivatization followed by reductive cleavage (DFRC) method [23].

\section{Compositional analysis}

The composition of the plant samples was analyzed using standard National Renewable Energy Laboratory procedures [24]. To calculate polysaccharide composition, monomer sugars were analyzed by high-performance liquid chromatography (HPLC) after acid hydrolysis of the samples. HPLC analysis of liquid samples was performed on a system consisting of a solventdelivery system (9010 Gradient HPLC Pump, Varian/ Agilent, Santa Clara CA, USA), an autosampler (717 Plus; Waters Corp., Milford, MA, USA), a carbohydrate analysis column (Aminex HPX-87H; Bio-Rad, Hercules, CA, USA); a refractive index detector (2414; Waters Corp.) a dual-wavelength absorbance detector (2487; Waters Corp.); and an integrator (HP3396G; Hewlett Packard, Santa Clara CA, USA). The mobile phase was $5 \mathrm{mmol} / \mathrm{l} \mathrm{H}_{2} \mathrm{SO}_{4}$ filtered through a $0.2 \mu \mathrm{m}$ nylon filter (Millipore Corp., Billerica, MA, USA) and degassed. The mobile phase flow rate was $0.6 \mathrm{ml} / \mathrm{min}$ and the column temperature was maintained at $60^{\circ} \mathrm{C}$ by a column heater (CH-30; Eppendorf) with a temperature controller (TC50; Eppendorf, Hauppauge, New York, USA).

\section{Cell-wall degradability analysis}

The stem materials were ground for passage through a 20 mesh $(841 \mu \mathrm{m})$ screen for cell-wall degradability analyses. Pretreatment was carried out by pressure cooking $50 \mathrm{mg}$ samples in a metal tube containing $1.5 \mathrm{ml}$ water at $200^{\circ} \mathrm{C}$ (30 seconds of heat-up time followed by a 10 minute hold). Each tube was placed in a fluidized sand bath (Tecam ${ }^{\circ}$ SBL-1; Cole-Parmer, Vernon Hills, IL). The pressure within the tubes was held at the saturation vapor pressure of water to keep the water in a liquid state $[9,11-13]$. The samples were cooled before the addition of $1.5 \mathrm{ml}$ of $100 \mathrm{mmol} / \mathrm{l}$ citrate buffer $\mathrm{pH} 4.8$, bringing the final volume to $3 \mathrm{ml}(\sim 2 \%$ solids $(\mathrm{w} / \mathrm{v}))$. For hot-water washing, samples were washed twice with $3 \mathrm{ml}$ of $70^{\circ} \mathrm{C}$ water. After the second wash, no glucose was detected. The enzyme hydrolysis for all the conditions tested was based on initial solids loading and glucan concentration. Commercial cellulase (Spezyme CP) at 0.2 filter paper units (FPU) $/ \mathrm{ml}$ or $50 \mathrm{FPU} / \mathrm{g}$ glucan 
(90 $\mathrm{mg}$ protein/g glucan) and $\beta$-glucosidase (Novozyme 188 ) at 0.35 cellobiase units $(\mathrm{CBU}) / \mathrm{ml}$ or $105 \mathrm{CBU} / \mathrm{g}$ glucan (34 $\mathrm{mg}$ protein/g glucan) were added, and hydrolysis was carried out for different lengths of time at $50^{\circ}$ $\mathrm{C}$ and $\mathrm{pH} 4.8$ in an incubator shaker (New Brunswick Scientific, Edison, NJ, USA). The ratio of enzyme to solids was equivalent to $10 \mathrm{FPU} / \mathrm{g}$ total solids, $21 \mathrm{CBU} / \mathrm{g}$ total solids and $25 \mathrm{mg}$ protein/g total solids. Enzyme hydrolysis of $50 \mathrm{mg}$ untreated samples (also at 2\% solids (w/v), $50^{\circ} \mathrm{C}$ and $\mathrm{pH} 4.8$ ) was carried out under similar experimental conditions.

\section{SEM analysis}

Stem cross-sections were adhered to a glass slide with epoxy adhesive (J-B Weld; J-B Weld Co., Sulphur Springs, TX, USA) and subjected to different treatments. Pretreatment was performed as described in the previous section. When applied, enzyme hydrolysis was carried out with a two-fold increase in enzyme loading to compensate for the particle size differences between the samples used for SEM and cell-wall degradability analysis. Subsequently, the stem cross-sections were fixed in two steps: first with a mixture of $2 \%$ paraformaldehyde and $2.5 \%$ glutaraldehyde in $0.1 \mathrm{~mol} / \mathrm{l}$ cacodylate buffer, $\mathrm{pH} 7.4$ for 1 hour and then with $1 \% \mathrm{OsO}_{4}$ in $0.1 \mathrm{~mol} / \mathrm{l}$ cacodylate buffer, $\mathrm{pH} 7.4$ for 30 minutes. After critical point drying, the samples were sputter-coated with gold, and viewed under SEM (Nova nanoSEM; Fei Co., Hillsboro, OR, USA).

\section{Protein and phenolic measurements}

The protein content of the commercial enzyme preparations was determined using a commercial kit (Pierce BCA Protein Assay Kit; product number 23225; Thermo Scientific, Rockford, IL, USA). Phenolic compounds were assayed using Prussian blue [25]. The diluted sample liquid ( $3 \mathrm{ml}$ aliquots) was transferred to a $10 \mathrm{~mm}$ cuvette, then $200 \mu \mathrm{L}$ of $0.008 \mathrm{~mol} / 1 \mathrm{~K}_{2} \mathrm{Fe}(\mathrm{CN})_{6}$ were added, followed by the immediate addition of $200 \mu \mathrm{L}$ of $0.1 \mathrm{~mol} / \mathrm{l} \mathrm{FeCl}_{3}$ in $0.1 \mathrm{~mol} / \mathrm{l} \mathrm{HCl}$. Absorbance was read at $700 \mathrm{~nm}$ after $5 \mathrm{~min}$ at room temperature, against a tannic acid standard.

\section{Acknowledgements}

We thank Junko Maeda, Xingya (Linda) Liu, Rick Hendrickson and Thomas Kreke for their technical assistance. We also thank Chia-Ping Huang at Purdue Life Science Microscopy Facility for assistance with SEM imaging. Finally, we are grateful for the enzymes provided by Genencor. This work was supported by USDA IFAFS contract \#00-52104-9663 and DOE grant \#DEFG02-06ER64301.

\section{Author details}

'Department of Biochemistry, Purdue University, West Lafayette, IN 47907 USA. ${ }^{2}$ Department of Agricultural and Biological Engineering and the Laboratory of Renewable Resources Engineering, Purdue University, West Lafayette, IN 47907, USA. ${ }^{3}$ Department of Forestry and Natural Resources,
Purdue University, West Lafayette, IN 47907, USA. ${ }^{4}$ Weldon School of Biomedical Engineering, Purdue University, West Lafayette, IN 47907, USA.

\section{Authors' contributions}

$\mathrm{XL}$ carried out the lignin analysis, participated in SEM imaging, and drafted the manuscript. EX participated in SEM imaging and helped to draft the manuscript. EX and MS carried out cell-wall degradability analyses. YK and MS carried out cell-wall compositional analysis and phenolic measurements. $\mathrm{XL}$ and CC conceived the study. CC, RM and ML participated in its design and coordination, and helped to draft the manuscript. All authors read and approved the final manuscript.

\section{Competing interests}

Michael Ladisch is Chief Technology Officer at Mascoma Corporation. Clint Chapple is the inventor on patents related to engineering $S$ lignin content in plants.

Received: 27 September 2010 Accepted: 2 December 2010 Published: 2 December 2010

\section{References}

1. Li X, Weng JK, Chapple C: Improvement of biomass through lignin modification. Plant J 2008, 54:569-581.

2. Reddy MS, Chen F, Shadle G, Jackson L, Aljoe H, Dixon RA: Targeted downregulation of cytochrome $\mathrm{P} 450$ enzymes for forage quality improvement in alfalfa (Medicago sativa L.). Proc Natl Acad Sci USA 2005, 102:16573-16578.

3. Huntley SK, Ellis D, Gilbert M, Chapple C, Mansfield SD: Significant increases in pulping efficiency in $\mathrm{C} 4 \mathrm{H}-\mathrm{F} 5 \mathrm{H}$-transformed poplars: improved chemical savings and reduced environmental toxins. J Agric Food Chem 2003, 51:6178-6183.

4. Chen F, Dixon RA: Lignin modification improves fermentable sugar yields for biofuel production. Nat Biotechnol 2007, 25:759-761.

5. Meyer K, Cusumano JC, Somerville C, Chapple CC: Ferulate-5-hydroxylase from Arabidopsis thaliana defines a new family of cytochrome P450dependent monooxygenases. Proc Natl Acad Sci USA 1996, 93:6869-6874.

6. Meyer K, Shirley AM, Cusumano JC, Bell-Lelong DA, Chapple C: Lignin monomer composition is determined by the expression of a cytochrome P450-dependent monooxygenase in Arabidopsis. Proc Natl Acad Sci USA 1998, 95:6619-6623.

7. Chapple CC, Vogt T, Ellis BE, Somerville CR: An Arabidopsis mutant defective in the general phenylpropanoid pathway. Plant Cell 1992, 4:1413-1424.

8. Marita JM, Ralph J, Hatfield RD, Chapple C: NMR characterization of lignins in Arabidopsis altered in the activity of ferulate 5-hydroxylase. Proc Natl Acad Sci USA 1999, 96:12328-12332.

9. Weil J, Sarikaya A, Rau SL, Goetz J, Ladisch C, Brewer M, Hendrickson R, Ladisch M: Pretreatment of corn fiber by pressure cooking in water. Appl Biochem Biotechnol 1998, 73:1-17.

10. $Y u$ G, Yano S, Inoue H, Inoue S, Endo T, Sawayama S: Pretreatment of rice straw by a hot-compressed water process for enzymatic hydrolysis. App/ Biochem Biotechnol 2010, 160:539-551.

11. Kim Y, Mosier NS, Ladisch MR: Enzymatic digestion of liquid hot water pretreated hybrid poplar. Biotechnol Prog 2009, 25:340-348.

12. Mosier N, Hendrickson R, Ho N, Sedlak M, Ladisch MR: Optimization of $\mathrm{pH}$ controlled liquid hot water pretreatment of corn stover. Bioresour Technol 2005, 96:1986-1993.

13. Mosier N, Wyman C, Dale B, Elander R, Lee YY, Holtzapple M, Ladisch M: Features of promising technologies for pretreatment of lignocellulosic biomass. Bioresour Technol 2005, 96:673-686.

14. Ximenes E, Kim Y, Mosier N, Dien B, Ladisch M: Inhibition of cellulases by phenols. Enzyme Microb Tech 2010, 46:170-176.

15. Ximenes E, Kim Y, Mosier N, Dien B, Ladisch M: Deactivation of cellulases by phenols. Enzyme Microb Tech 2010, Accepted for publication on 3 Sept 2010.

16. Ralph J, Lapierre C, Marita JM, Kim H, Lu F, Hatfield RD, Ralph S, Chapple C, Franke $\mathrm{R}$, Hemm MR, et al: Elucidation of new structures in lignins of CAD- and COMT-deficient plants by NMR. Phytochemistry 2001, 57:993-1003. 
17. Ralph J, Akiyama T, Kim H, Lu F, Schatz PF, Marita JM, Ralph SA, Reddy MS Chen F, Dixon RA: Effects of coumarate 3-hydroxylase down-regulation on lignin structure. J Biol Chem 2006, 281:8843-8853.

18. Franke R, Hemm MR, Denault JW, Ruegger MO, Humphreys JM, Chapple C: Changes in secondary metabolism and deposition of an unusual lignin in the ref8 mutant of Arabidopsis. Plant J 2002, 30:47-59.

19. Kristensen JB, Thygesen LG, Felby C, Jorgensen H, Elder T: Cell-wall structural changes in wheat straw pretreated for bioethanol production. Biotechnol Biofuels 2008, 1:5.

20. Selig MJ, Viamajala S, Decker SR, Tucker MP, Himmel ME, Vinzant TB: Deposition of lignin droplets produced during dilute acid pretreatment of maize stems retards enzymatic hydrolysis of cellulose. Biotechnol Prog 2007, 23:1333-1339.

21. Stewart JJ, Akiyama T, Chapple C, Ralph J, Mansfield SD: The effects on lignin structure of overexpression of ferulate 5-hydroxylase in hybrid poplar. Plant Physiol 2009, 150:621-635.

22. Sathitsuksanoh N, Zhu Z, Ho TJ, Bai MD, Zhang Y-HP: Bamboo saccharification through cellulose solvent-based biomass pretreatment followed by enzymatic hydrolysis at ultra-low cellulase loadings. Bioresour Technol 2010, 101:4926-4929.

23. Lu FC, Ralph J: Derivatization followed by reductive cleavage (DFRC method), a new method for lignin analysis: Protocol for analysis of DFRC monomers. J Agric Food Chem 1997, 45:2590-2592.

24. Ruiz R, Ehrman T: NREL analytical procedure: LAP 002. Determination of carbohydrates in biomass by high performance liquid chromatography. National Renewable Energy Laboratory, Golden, CO; 1996.

25. Budini R, Tonelli D, Girotti S: Analysis of total phenols using the Prussian Blue method. J Agric Food Chem 1980, 28:1236-1238.

doi:10.1186/1754-6834-3-27

Cite this article as: Li et al.: Lignin monomer composition affects Arabidopsis cell-wall degradability after liquid hot water pretreatment. Biotechnology for Biofuels 2010 3:27.

\section{Submit your next manuscript to BioMed Central and take full advantage of:}

- Convenient online submission

- Thorough peer review

- No space constraints or color figure charges

- Immediate publication on acceptance

- Inclusion in PubMed, CAS, Scopus and Google Scholar

- Research which is freely available for redistribution

Submit your manuscript at www.biomedcentral.com/submit 